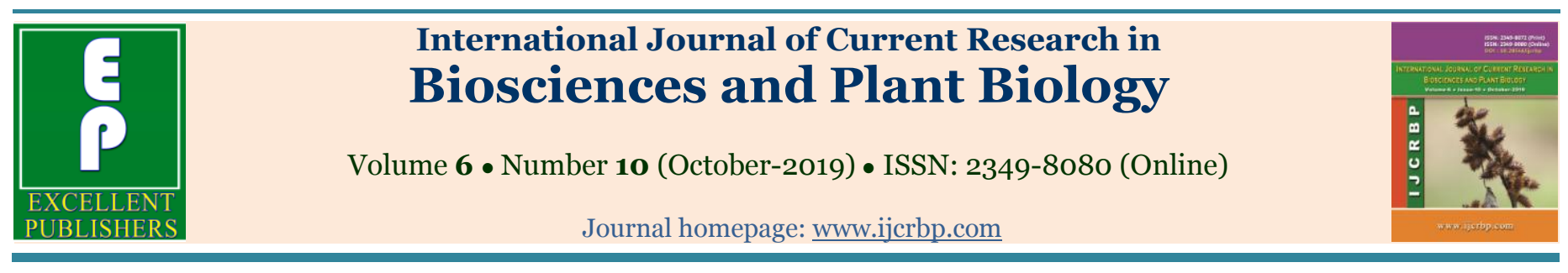

\title{
The comparative antibacterial effect of aqueous extract of Carica papaya leaves and Carica papaya nanoparticles against selected bacteria
}

\author{
T. Temikotan, A. O. Daniels*, B. J. Samuel and A. O. Akinkugbe \\ Achievers University, Owo, Ondo State, Nigeria \\ *Corresponding author; e-mail: toyosidanny@yahoo.com
}

\begin{tabular}{|c|c|}
\hline Article Info & ABSTRACT \\
\hline $\begin{array}{l}\text { Date of Acceptance: } \\
11 \text { September } 2019\end{array}$ & \multirow{3}{*}{$\begin{array}{l}\text { Silver salt and its colloidal formulations have been used since ancient times to treat } \\
\text { ulcers, burns chronic wounds and other infections but its use was discontinued due to } \\
\text { the interfering effects of salt and the development of new antibiotics, However, almost a } \\
\text { decade back, renew interest grew for nanosilver owing to its high surface area to volume } \\
\text { ratio and size-dependent unique optical, electrical, and thermal properties. Silver } \\
\text { nanoparticles were synthesized using eco-friendly method with extract of Carica } \\
\text { papaya as reducing and stabilizing agent. The silver nitrate solution was used as } \\
\text { precursor. A visible colour change from yellow to dark brown confirmed the formation } \\
\text { of the nanoparticles and the UV-Vis spectroscopy showed an absorbance of o.69 at } \\
\text { wavelength } 435 \mathrm{~nm} \text { for the silver nanoparticle. The antimicrobial activity of the } \\
\text { synthesized nanoparticles was studied against Escherichia coli, Salmonella typhi and } \\
\text { Staphylococcus aureus. The silver nanoparticles biosynthesized showed antimicrobial } \\
\text { activity against the test isolates with zone of inhibition ranging from } 10-15 \mathrm{~mm} \text {. } \\
\text { Antimicrobial activity of silver nanoparticles was statistically significant as compared to } \\
\text { Chloramphenicol at o.o5\% level of confidence. Generally, the Minimum Inhibitory } \\
\text { Concentration (MIC) and Minimum Bactericidal Concentration (MBC) values for Silver } \\
\text { nanoparticle ranged from o.22 - o.42 g/ml and } 1-30 \text { cfu/ml respectively, against the } \\
\text { test organisms. S. aureus was most sensitive while E. coli and } S \text {. typhi were least } \\
\text { sensitive to silver nanoparticles, while the activities of } C \text {. papaya extract ranged from } \\
\text { o.32 - o.42 g/ml and } 6-36 \text { cfu/ml respectively, against the test organisms } E \text {. coli and } S \text {. } \\
\text { aureus were more sensitive while } S \text {. typhi was least sensitive to C. papaya nanoparticles. }\end{array}$} \\
\hline Keywords & \\
\hline $\begin{array}{l}\text { Antimicrobial activity } \\
\text { Carica papaya } \\
\text { Minimum Bactericidal } \\
\text { Concentration } \\
\text { Minimum Inhibitory } \\
\text { Concentration } \\
\text { Nanoparticles }\end{array}$ & \\
\hline
\end{tabular}

\section{Introduction}

Silver has been used since ancient times for its microbicidal properties. Silver salt and its colloidal formulations have been used to treat ulcers, burns and chronic wounds, sepsis, acute epididymitis, tonsillitis, and infections and to prevent eye diseases in infants (Sintubin et al., 2011), but its use was discontinued due to the interfering effects of salt and the development of effective new antibiotics (Edwards-Jones, 2009). However, almost a decade back, nanosilver made a remarkable comeback owing to its high surface area to volume ratio and size-dependent unique optical, electrical, and thermal properties (Schmid, 1992). Silver nanoparticles (AgNPs) are now one of 
the most commercialized nanomaterials having applications in over 200 products such as antimicrobial coatings, medical devices, molecular diagnostics and photonic devices, sensors, textiles, home water purifiers, cosmetics, electronics, household appliances, conductive inks, pastes, and fillers (Lin et al., 2011; Sintubin et al., 2011; Wijnhoven et al., 2009). Based on their structure, polymeric nanoparticles can be classified into nanocapsules and nanospheres. Based on the composition, nanoparticles are classified as:i) Organic nanoparticles, ii) Inorganic nanoparticles, iii) Organic -inorganic hybrids, iv) Carbonaceous nanostructure, v) Liposome that can be filled with specific materials, vi) Biological nanoparticles such as proteins and viruses.

Silver is a well-known antimicrobial agent against a wide range of over 650 microorganisms from different classes such as Gram-negative and Grampositive bacteria, fungi or viruses (Nakkala et al., 2014).Silver has been described as therapeutic agent for many diseases (Veeraputhiran, 2013). In the $18^{\text {th }}$ century, during childbirth it became a common practice to administer drops of aqueous silver nitrate to newborn's eyes to prevent the transmission of Neisseria gonorrhoea from infected mothers (Daniel et al., 2014). Silver nanoparticles synthesized using plant extracts (from different sources) have been used for analyzing their antimicrobial activities against different microbes. Nanoparticles have been shown to accumulate inside the membrane and can subsequently penetrate into the cells causing damage to cell wall or cell membranes (Kalishwarlal et al., 2010).

It is thought that silver atoms bind to thiol groups of enzymes forming stable SAAg bonds with thiol containing compounds and then it causes the deactivation of enzymes in the cell membrane that involve in trans membrane energy generation and ion transport. It was proposed that $\mathrm{Ag}^{+}$ions enters the cell and intercalates between the purine and pyrimidine base pairs disrupting the hydrogen bonding between the two anti-parallel strands and denaturing the DNA molecule. Bacterial cell lysis could be one of reason for its antibacterial property (Geetha et al., 2014).

\section{Carica papaya}

Carica papaya is an evergreen shrub or small tree that grows best in full sun to light shade. The papaya plant has been described with a large variety of adjectives, which acknowledge the structural and functional complexity of this giant tropical herb. C. papaya, with a somatic chromosome number of 18 , is the sole species of this genus of the Caricaceae, a family well represented in the Neotropics, which includes six genera with at least 35 species (Fisher, 2008). $C$. papaya as well the leaf is a good source of Vitamin A (Carotene), Vitamin B1 (Thiamine), Vitamin B2 (Riboflavin), Vitamin C (Ascorbic acid), Vitamin E, Niacin, Minerals such as Calcium, Iron, Phosphorous, Potassium, Proteins, Fats, Calories, Carbohydrates, $\beta$-carotene, Fibers and Folate that helps to boost the number of platelets present in the blood (Ming et al., 2008). C. papaya is used in the treatment of various human diseases and also has a great potential in suppressing various plant pathogenic fungi (Nguegno et al., 2017; Murthy et al., 2019).

This research seeks to synthesize silver nanoparticles from $C$. papaya, with the aim of investigating its antimicrobial properties against selected bacterial strain. More importantly it may serve as a guideline for further investigation.

\section{Materials and methods}

\section{Plant sampling and preparation}

C. papaya leaves were collected from the compound of Achievers University, Owo and taken to the laboratory. The samples were authenticated by Dr T. Temikotan, a plant Biologists in the Department of Biological Sciences of Achievers University, Owo. The plant samples were washed thoroughly under running tap to remove dirts and debris and subjected to various analyses as described in the following text.

\section{Proximate analysis of plant material}

Plant material was subjected to proximate analysis which includes: moisture content, ash and lipid, crude fiber.

\section{Moisture content}

A $5 \mathrm{~g}$ portion of the papaya leaves was transferred to crucible and placed in the oven at $105^{\circ} \mathrm{C}$ for 1 
hour, then removed from the oven and put in desiccators and allowed to cool. The sample was weighed (the sample + crucible) and recorded. Then it was transferred back to the oven at $105^{\circ} \mathrm{C}$ for 30 minutes then return back to desiccator to cool and weighed, the procedure was repeated until a constant weight was observed.

The moisture content was established as shown below.

Crucible + papaya leaves - crucible $=$ weight of the leaves moisture content

$\frac{\text { Weight of fresh sample - Weight of the dry sample }}{\text { Weight of the fresh sample }} \times 100 \%$

\section{Ash content}

A $5 \mathrm{~g}$ portion of the papaya leaves was transferred to crucible and then placed into the muffle furnace at $200^{\circ} \mathrm{C}$ for 1 hour.

\section{Lipid content}

Cleaned and dried crucible was weighed as $\mathrm{w}_{1}$ and $5 \mathrm{~g}$ oven dried sample was added and re-weighed as $\mathrm{w}_{2}$. Round bottom flask with petroleum ether (40$60^{\circ} \mathrm{C}$ ) up to three quarter of the flask, Soxhlet extractor was fixed with reflux condenser and the heat source was adjusted so that the solvent boils gently. The samples were put inside the thimble and inserted into the Soxhlet apparatus and extract under reflux was carried out with petroleum ether $\left(40-60^{\circ} \mathrm{C}\right)$ after the barrel of the extractor is emptied, the condenser was removed and the thimble was removed, taken into oven at $100^{\circ} \mathrm{C}$ for one hour and later cooled in the desiccators and weighed again $\left(\mathrm{w}_{3}\right)(\mathrm{AOAC}, 2015)$.

$\%$ Fat weight loss sample $=\frac{\mathrm{w}_{2}-\mathrm{W}_{1} \times 100}{\mathrm{w}_{3}-\mathrm{w}_{1} \times 1}$

Solvents: pet ether, $\mathrm{N}$ - hexane, dichloromethane and chloroform.

\section{Fibre content}

A $2 \mathrm{~g}$ portion $C$. papaya leaves $\left(\underline{\mathrm{w}}_{1}\right)$ was weighed and put into $250 \mathrm{ml}$ beakers. $50 \mathrm{ml}$ of $1.25 \% \mathrm{H}_{2} \mathrm{SO}_{4}$ acid solution was added and made up to $200 \mathrm{ml}$ with distilled water and stirred. The mixture was heated with continuous stirring for thirty (30) minutes and allowed to cool and settle. Distilled water was added and allowed to settle, then decanted $\left(\underline{\mathrm{w}}_{2}\right)$. Decantation was repeated for six (6) times consecutively to make the mixture acid free. $50 \mathrm{ml}$ of $1.25 \% \mathrm{NaOH}$ was added to the mixture and made up to $200 \mathrm{ml}$ with distilled water in a beaker, and heated for thirty minutes with continuous stirring. It was allowed to cool and settle. Distilled water was added and decanted for six (6) times. The mixture was filtered with filter paper and kept for about forty-five minutes (45) for water todrain completely, and weights taken $\left(\underline{\mathrm{w}}_{3}\right)$.

$$
\% \text { Crude fiber }=\frac{\mathrm{w}_{2}-\mathrm{w}_{3}}{\mathrm{w}_{1}}
$$

\section{Protein content}

A $5 \mathrm{~g}$ of sample was dissolved with $30 \mathrm{ml}$ of concentrated sulphuric acid using $2 \mathrm{~g}$ of copper sulphate and 16.0 g of sodium sulphate salt until a clear green solution was obtained. This was dissolved in distilled water and made up to $100 \mathrm{ml}$ in a volumetric flask; $12.5 \mathrm{ml}$ of the digest was measured into a semi-micro Kjeldahl Markham distillation apparatus and treated with $12.5 \mathrm{ml}$ of $1.25 \%$ of sodium hydroxide $(\mathrm{NaOH})$ solution. This was distilled with $10 \mathrm{ml}$ of boric acid and double indicator. The distillate was then titrated with $0.1 \%$ $\mathrm{HCl}$ solution until a light pink end point was reached. Blank titration was also carried out in similar manner. Distillation was carried out in triplicate and the percentage nitrogen obtained by appropriate calculation.

$\%$ Nitrogen $=$

$\frac{\mathrm{Ml} \text { of } \mathrm{HCl}(\text { blank })-\mathrm{Ml} \text { of } \mathrm{HCl}(\text { sample }) \times 0.1 \mathrm{M} \mathrm{HCl} \times 14 \times 100 \times 100}{\text { Weight of sample } \times \mathrm{Ml} \text { of digest } \times 1000} \times 6.25$

\section{Phytochemical analysis}

The analysis for tannin, saponins, cardiac glycosides and alkaloids were carried out according to standard methods (Sofowara, 1993; AOAC, 1980).

\section{Presence of alkaloids}

About $0.5 \mathrm{~g}$ of the dried sample of the plant each 
group was acidified with 1\% HCL. About $3 \mathrm{ml}$ of each extract was treated with drops of Mayer's reagent another portion with Drangedonff's reagent. Creamy white (Mayer) orange (Drangedonff) precipitates indicate the presence of alkaloids.

\section{Presence of saponins using frothing test}

Five $\mathrm{ml}$ of the extract was vigorously shaken for two 2 minutes. Formation of stable froth was taken as evidence of the presence of saponin.

\section{Presence of cardiac glycosides using Keller- Killani test}

A $5 \mathrm{ml}$ of the extracts was treated with $2 \mathrm{ml}$ of glacial acetic acid containing a drop of iron iii chlorine $\mathrm{FeCl}_{3}$ solution. This was underlayed with $1 \mathrm{ml}$ of conc. $\mathrm{H}_{2} \mathrm{SO}_{4}$. A brown ring at the interface indicated the presence of a deoxysugar characteristic of cardenolides. A violet ring may appear below the brown ring while in the acetic acid layer a greenish ring may form just gradually throughout the thin layer.

\section{Presence of tannins}

Two drops of $5 \%$ ferric chloride $\mathrm{FeCl}_{3}$ were added to $1 \mathrm{ml}$ of each extract. A dirty green precipitates indicated the presence of tannins. In the alternative about $1 \mathrm{~g}$ of each sample was boiled in $20 \mathrm{ml}$ of distilled water in a test tube and then filtered. A few drops of $0.1 \%$ ferric chloride were added. A dirty - green colour or blue black colouration was observed. This indicated the presence of tannins.

\section{Collection and maintenance of microorganisms}

Clinical strain of bacteria samples (Escherichia coli, Salmonella typhi and Staphylococcus aureus) was collected from Federal Medical Centre Owo, Ondo State on agar slant and sample were subjected to biochemical confirmatory test.

\section{Preparation of plant material}

After thorough washing, the plant materials were air dried for 10 days under room temperature. The dried parts were ground to coarse powder using thoroughly washed electric home blender machine and kept in clean covered glass containers till needed for extraction.

\section{Extraction procedure}

A $25 \mathrm{~g}$ portion of fine powder of papaya leaves was dissolved in $200 \mathrm{ml}$ water and it was thoroughly shaken to dissolve the powder into the solvent. Then it was heated at $60^{\circ} \mathrm{C}$ for $5-10$ minutes and was shaken intermittently during the process for more interaction between the powdered particles and the solvent and then incubated in water bath for $30 \mathrm{~min}$ to facilitate the formation of aqueous extract (Morsy et al., 2014). After the extraction process the plant extracts was filtered with sterilized cotton filter and filter paper. The filtrate was collected in a beaker. This process was repeated three times using cotton and filter paper. Then the filtrate was decanted into a volumetric flask over a $40 \mu \mathrm{l}$ milipore filter and covered with aluminum foil paper and kept in the refrigerator.

\section{Synthesis of nanoparticle from C. Papaya using silver nitrate $\left(\mathrm{AgNO}_{3}\right)$}

The modified method of Banala et al. (2015): was used in the synthesis of Silver nitrate from $C$. papaya. A $0.421 \mathrm{~g}$ part of silver nitrate salt $\left(\mathrm{AgNO}_{3}\right.$, Kermel Nigeria), was added to $100 \mathrm{ml}$ of distilled water to dissolve thoroughly. The solution obtained was transferred to an amber coloured bottle to prevent autoxidation of silver. An equal quantity of $C$. Papaya crude extract was also suspended in 10oml of water and mixed thoroughly. A $5 \mathrm{ml}$ aliquot of C. papaya solution was dispensed into a conical flask and $20 \mathrm{ml}$ of 1 $\mathrm{mM} \mathrm{AgNO}_{3}$ was mixed with it (in the ratio 1:4). The solution was then heated in a water bath at $60^{\circ} \mathrm{C}$ for 30 min until change in colour was observed. A colour change indicates the formation of silver nanoparticles (Baruwati et al., 2009).

\section{Standardization of inocula (preparation of Macfarland's constant)}

One percentage (1\%) of solution of sulphric acid was prepared and mixed properly. Also, 1\% solution of barium chloride was prepared by dissolving $0.5 \mathrm{~g}$ of dehydrated barium chloride $\left(\mathrm{BaCl}_{2} \mathrm{H}_{2} \mathrm{O}\right)$ in $5 \mathrm{Oml}$ of distilled water. $\mathrm{A} 0.5 \mathrm{ml}$ of aliquot of barium chloride solution was added to 
$99.5 \mathrm{ml}$ of sulphuric acid solution and it was mixed together. The solution was transferred into a capped tube of the same type used for both control and the test inocula. The solution was kept at room temperature of $27^{\circ} \mathrm{C}$. and was used to standardize the inocula by comparing the absorbance using a spectrophotometer (Michael et al., 2010).

\section{Preparation of chloramphenicol (control)}

Antibiotic weighing 0.421g (chloramphenicol) was dissolved in $100 \mathrm{ml}$ of distilled water and kept under sterile condition.

\section{Evaluation of antibacterial activity of extracts}

Test organisms were suspended in nutrient broth and incubated for 4 hours to obtain a concentration corresponding to McFarlands constant $\left(0.5^{\times} 10^{-8} \mathrm{cfu} / \mathrm{ml}\right)$. The inoculums were standardized with the prepared barium sulphate solution as described above. Sterile Petri dishes were inoculated by the pour plate method. $1 \mathrm{ml}$ of the test inoculums was pipetted aseptically into each Petri dish and about 20ml of sterilized nutrient agar was poured into the inoculated Petri dish. The agar plates were allowed to set. Wells of $6 \mathrm{~mm}$ diameter were made over the agar plates equidistant from each other using sterile cork borer (bore 4 holes) on the set plate. $0.5 \mathrm{ml}$ portion of silver nanoparticles, C. papaya extract, silver nitrate and chloramphenicol were introduced into the wells using micropipette. Distilled water was used as negative control. The extracts were allowed to diffuse into agar for about 20 minutes after which the plates were incubated for 24 hours at $37^{\circ} \mathrm{C}$. Thereafter the diameter of inhibition zones formed around each well was measured in $\mathrm{mm}$ and recorded. The experiments were replicated in triplicates and the values recorded (Cheesebrough, 2006).

\section{Determination of Minimum Inhibitory Concentration (MIC) and Minimum Bactericidal Concentration (MBC)}

The Minimum Inhibitory Concentration (MIC) of the extracts was determined for each of the test organisms in triplicate in test tubes. To $0.5 \mathrm{ml}$ of varying concentrations of the extracts (0.42, 0.32, 0 . 22, $0.12,0.2 \mathrm{~g} / \mathrm{ml}$ ) in test tubes, Nutrient broth (2ml) was added and then a loopful of the test organism, previously diluted to $0.5 \mathrm{McF}$ arland turbidity standards, was introduced. The procedure was repeated on the test organisms using the aliquots (silver nanoparticle, silver nitrate and pawpaw leaf extract). Tubes containing Nutrient broth only were seeded with the test organisms, as described above, to serve as controls. The culture tubes were then incubated at $37^{\circ} \mathrm{C}$ for 24 hours. After incubation the tubes were then examined for microbial growth by observing for turbidity.

To determine the $\mathrm{MBC}$, for each set of test tubes in the MIC determination, a loopful of broth was collected from those tubes that did not show any growth and inoculated onto sterile Nutrient agar by streaking. Nutrient agar plates only were also streaked with the respective test organisms to serve as controls. All the plates were then incubated at $370 \mathrm{C}$ for $24 \mathrm{~h}$. After incubation the concentration at which no visible growth was seen was noted as the Minimum Bactericidal Concentration (MBC).

\section{Statistical analysis}

Results obtained were subjected to statistical analysis using T- test to separate the means values of the data collected.

\section{Results}

Table 1 shows the results of the proximate composition of the C. papaya. The moisture content was $84 \%$, ash content was $8 \%$, fibre was $16 \%$, lipid content was $6 \%$ crude protein was $5.1 \%$ and carbohydrate was $66 \%$.

Table 1. Result of proximate composition of the Carica papaya leaves.

\begin{tabular}{lll}
\hline Sl. No. & Parameters & Percentage (\%) \\
\hline 1 & Moisture content & 84.0 \\
2 & Ash content & 8.0 \\
3 & Fibre content & 16.0 \\
4 & Lipid content & 6.0 \\
5 & Crude protein & 5.1 \\
6 & Carbohydrate content & 66.0 \\
\hline
\end{tabular}

\section{Phytochemical screening of papaya leaves}

The phytochemical analysis of the leaves (Table 2) showed that the leaves contained saponins, cardiac 
glycosides, and alkaloids. Tannin was absent in the leaves.

Table 2. Phytochemical screening of Carica papaya leaves.

\begin{tabular}{ll}
\hline Constituents & Result \\
\hline Saponins & + \\
Tannins & - \\
Cardiac glycoside & + \\
Alkaloid & + \\
\hline + Represent; - No activity; &
\end{tabular}

\section{UV-Vis spectral analysis (characterization of synthesized nanoparticles)}

The eco-friendly synthesis of AgNP was performed under a reflux environment using $C$. papaya $\mathrm{L}$. extract. The $\mathrm{Ag}+$ ion reduction was confirmed by the apparent transformation in the colour of the reaction mixture from yellow to dark brown. Indeed, no color transformation was noticed in the absence of plant extract, under a similar set of circumstances. The formation of AgNP was further confirmed by UV-Vis spectral study, which is an authentic technique to monitor the progress of the reaction during the reduction of $\mathrm{Ag}+$ ions. For this purpose, UV-Vis spectra of green synthesized AgNP prepared at $60{ }^{\circ} \mathrm{C}$ were measured as displayed in Fig. 1 below.

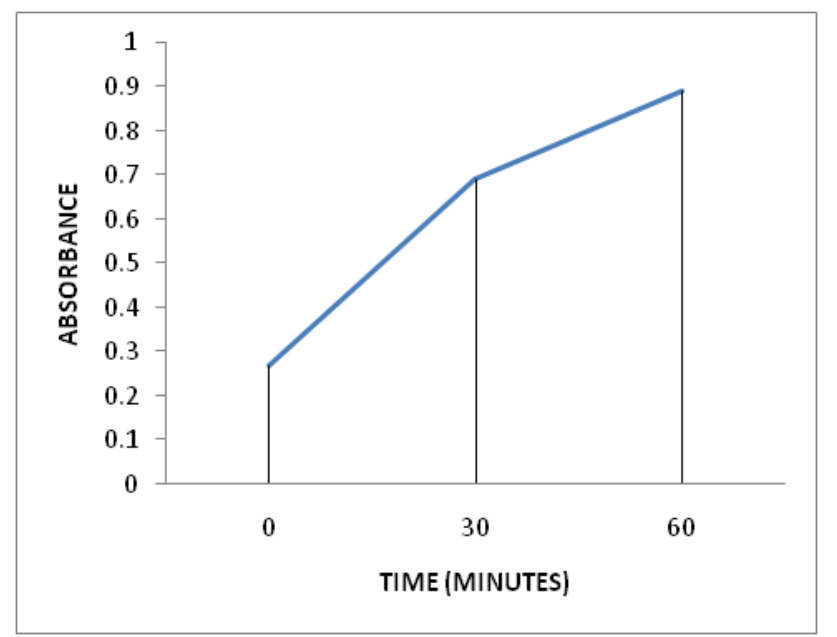

Fig. 1: UV-Vis analysis of Ag NPs synthesized from Carica papaya.

The kinetics of the reaction monitored by UV-Vis analysis revealed that the reaction was slow in the beginning; indeed, up to 30 minutes from the start of the reaction, no indication of the formation of NPs was observed (no Ag peak). After 30 minutes, the nucleation was initiated very rapidly and the formation of AgNP occurred very fast until around 30 minutes had passed. This is clearly reflected by the sudden appearance of the characteristic band of AgNP at $\sim 430 \mathrm{~nm}$ after 60 minutes of reaction time (blue line in Fig. 1). The reaction was allowed to continue further and no considerable change was observed in the intensity of the Ag peak, which points towards the completion of the reaction in 60 minutes.

\section{Antimicrobial activity}

The antimicrobial activity of silver nanoparticles was investigated against one Gram positive and two Gram negative bacteria. The synthesized silver nanoparticles exhibited good antibacterial activity against both Gram positive and Gram negative bacteria. The AgNP showed an inhibition of $10 \pm$ $1.5 \mathrm{~mm}$ against $S$. typhi, which was not statistically lower than an inhibition of $12 \pm 2.5 \mathrm{~mm}$ of the standard antibiotic, but chloramphenicol was significantly higher than the inhibition of $3 \pm 0.5$ $\mathrm{mm}$ and $6 \pm 1.5 \mathrm{~mm}$ of silver nitrate and pawpaw extract respectively. Its inhibition of $12 \pm 1.5 \mathrm{~mm}$ against $E$. coli, was statistically lower than that of 14 $\pm 2.5 \mathrm{~mm}$ than that of chloramphenicol but highly significant than those of silver nitrate and papaya extract with the inhibition values of $2 . \pm 0.5 \mathrm{~mm}$ and $9 \pm 1.5 \mathrm{~mm}$, respectively. The inhibition by AgNP against $S$. aureus was $15 \pm 1.5 \mathrm{~mm}$. This showed statistically significant value that was higher than those of chloramphenicol with inhibition value of $12 \pm 0.5 \mathrm{~mm}$ and silver nitrate with inhibition of 5 $\pm 0.5 \mathrm{~mm}$ but not significantly higher than that of papaya extract with inhibition of $8 \pm 1.5 \mathrm{~mm}$.

\section{Determination of Minimum Inhibitory Concentration (MIC)}

The MIC of the extracts as presented in Fig. 2 shows Ag NP inhibited the selected organisms at $0.32 \mathrm{~g} / \mathrm{ml}, 0.22 \mathrm{~g} / \mathrm{ml}$ and $0.42 \mathrm{~g} / \mathrm{ml}$ against $S$. typhi, $S$. aureus and $E$. coli respectively. Silver nitrate inhibited the selected organisms: $S$. typhi, $S$. aureus and $E$. coli at $0.42 \mathrm{~g} / \mathrm{ml}, 0.32 \mathrm{~g} / \mathrm{ml}$ and $0.42 \mathrm{~g} / \mathrm{ml}$ respectively. The MIC of C. papaya leaf extract against the selected organisms: for $S$. typhi $0.32 \mathrm{~g} / \mathrm{ml}$, while for $S$. aureus $0.42 \mathrm{~g} / \mathrm{ml}$ and for $E$. coli $0.32 \mathrm{~g} / \mathrm{ml}$. The MIC of chloramphenicol against $S$. typhi was $0.22 \mathrm{~g} / \mathrm{ml}$, while for $S$. aureus $0.32 \mathrm{~g} / \mathrm{ml}$ and $0.32 \mathrm{~g} / \mathrm{ml}$ for $E$. coli. 
Table 3. Antibacterial activity of each sample against selected organisms.

\begin{tabular}{llll}
\hline Test organisms & Chl / AgNP & Chl / AgNO & Chl / PE \\
\hline Salmonella typhi & $12 \pm 2.5 \mathrm{~mm}$ & $12 \pm 2.5 \mathrm{~mm}$ & $12 \pm 2.5 \mathrm{~mm}$ \\
& $10 \pm 1.5 \mathrm{~mm}$ & $3 \pm 0.5 \mathrm{~mm}$ & $6 \pm 1.5 \mathrm{~mm}$ \\
& $\mathrm{Ns}$ & Sig & Sig \\
Escherichia coli & $14 \pm 2.5 \mathrm{~mm}$ & $14 \pm 2.5 \mathrm{~mm}$ & $14 \pm 2.5 \mathrm{~mm}$ \\
& $12 \pm 1.5 \mathrm{~mm}$ & $2 \pm 0.5 \mathrm{~mm}$ & $9 \pm 1.5 \mathrm{~mm}$ \\
Staphylococcus aureus & Sig & Sig & Sig \\
& $12 \pm 0.5 \mathrm{~mm}$ & $12 \pm 0.5 \mathrm{~mm}$ & $12 \pm 0.5 \mathrm{~mm}$ \\
& $15 \pm 1.5 \mathrm{~mm}$ & $5 \pm 0.5 \mathrm{~mm}$ & $8 \pm 1.5$ \\
\hline
\end{tabular}

NOTE: Upper values are for the standard antibiotic, chloramphenicol, while lower values in each cell belong to the various reagents as symbolized in the legend.

LEGEND: $\mathrm{Chl}=$ chloramphenicol; $\mathrm{AgNP}=$ Silver Nanoparticle; $\mathrm{AgNO}_{3}=$ Silver nitrate and $\mathrm{PE}=$ Papaya leaf extract; $\mathrm{ns}=$ no significant difference; sig = significant difference.

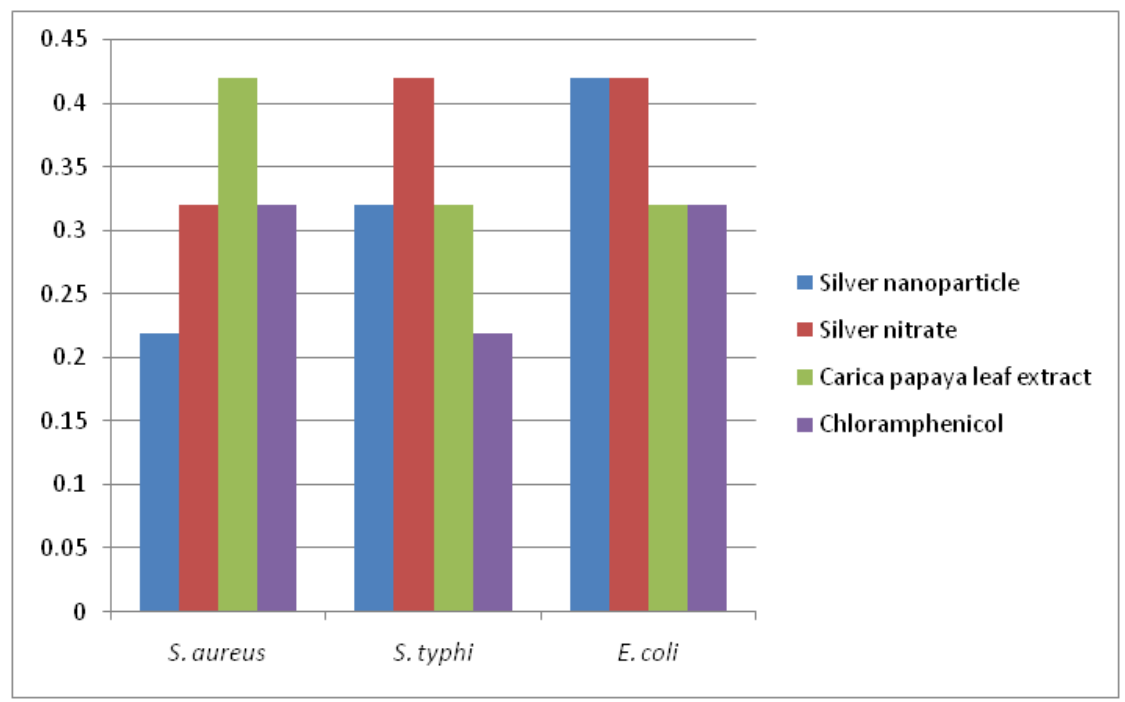

Fig. 2: Minimum Inhibitory Concentration (MIC).

\section{Determination of Minimum Bactericidal Concentration (MBC)}

The MCB as presented in Table 4 shows that all the extracts had little or no bactericidal activity against the selected organisms. Colony forming unit for silver nanoparticle ranged from $1-21 \mathrm{cfu} / \mathrm{ml}$ in $S$. aureus, $2-30 \mathrm{cfu} / \mathrm{ml}$ in E. coli, and 6-50 $\mathrm{cfu} / \mathrm{ml}$ in $S$. typhi. Colony forming unit for Silver nitrate ranged from $11-29 \mathrm{cfu} / \mathrm{ml}$ in $S$. aureus, $9-65$ $\mathrm{cfu} / \mathrm{ml}$ in $E$. coli and $7-36 \mathrm{cfu} / \mathrm{ml}$ in $S$. typhi. For C. papaya, colony forming unit ranged from 6-36 $\mathrm{cfu} / \mathrm{ml}$ all the selected organisms. The colony forming unit for chloramphenicol ranged from 2-30 $\mathrm{cfu} / \mathrm{ml}$ in the selected microorganisms (E. coli, $S$. typhi, and $S$. aureus), at all concentrations (0.42 $\mathrm{g} / \mathrm{ml}, \quad 0.32 \mathrm{~g} / \mathrm{ml}, \quad 0.22 \mathrm{~g} / \mathrm{ml}$ and $0.12 \mathrm{~g} / \mathrm{ml}$ ) (Table 4).

Table 4. Minimum Bactericidal Concentration (MIC).

\begin{tabular}{lllllllllllll}
\hline $\begin{array}{l}\text { Conc. } \\
\text { (g/ml) }\end{array}$ & $\begin{array}{l}\text { Ng } \\
\text { N }\end{array}$ & Ag NO & P.E & CHL & Ag NP & Ag NO & P.E & CHL & Ag NP & Ag NO & P.E & CHL \\
\hline 0.42 & 3 & 11 & 6 & 3 & 2 & 9 & 6 & 2 & 1 & 6 & 7 & 4 \\
0.32 & 7 & 16 & 14 & 10 & 9 & 13 & 15 & 8 & 7 & 14 & 17 & 11 \\
0.22 & 16 & 21 & 21 & 15 & 22 & 31 & 23 & 17 & 13 & 24 & 25 & 16 \\
0.12 & 19 & 24 & 27 & 19 & 25 & 53 & 28 & 19 & 15 & 39 & 30 & 23 \\
0.02 & 24 & 29 & 34 & 27 & 30 & 65 & 33 & 24 & 21 & 50 & 36 & 30 \\
\hline
\end{tabular}

Key: Ag NO $\rightarrow$ Silver nitrate; Ag NP $\rightarrow$ Silver nanoparticles; CHL $\rightarrow$ Chloramphenicol; P.E $\rightarrow$ Carica papaya leaf extract. 


\section{Optical density}

The optical density (OD) for all the extract (Silver nanoparticle, Silver nitrate, $C$. papaya, chloramphenicol) was determined at wavelength 430nm and silver nanoparticle had the highest absorbance of 0.69 and silver had the lowest absorbance of 0.27 as shown in Table 5 .

Table 5. Optical density for each extract at $430 \mathrm{~nm}$.

\begin{tabular}{ll}
\hline Extract & Optical density \\
\hline Silver Nanoparticles & 0.69 \\
Silver Nitrate & 0.27 \\
Carica papaya & 0.43 \\
Chloramphenicol & 0.47 \\
\hline
\end{tabular}

\section{Discussion}

The phytochemicals present in the leaves of $C$. papaya could be responsible for the high medicinal properties. The presence of saponins supports the fact that pawpaw leaf has cytotoxic effects such as permealization of the intestine as saponins are cytotoxic (Okwu and Okwu, 2004). It also gives the leaves the bitter taste. Alkaloids are the most efficient therapeutically significant plant substance. Pure isolated alkaloids and the synthetic derivatives are used as basic medicinal agents because of their analgesic, antispasmodic and bacterial properties (Stray, 1998). The presence of alkaloids in the leaves shows that these plants can be an effective anti-malarial agents, since alkaloids consist of quinine, which is an antimalaria. The cardiac glycosides therapeutically have the ability to increase the force and power of the heart-beat without increasing the amount of oxygen needed by the heart muscle (Okwu and Okwu, 2004).

Results obtained in this study suggest that silver nanoparticles synthesized with C. papaya leaf extract could be used as an effective antibacterial material against $S$. typhi, E. coli, and $S$. aureus, these infectious bacterial causes a number of diseases, including typhoid, bacteraemia, chronic wound infection, septic arthritis, skin and soft tissue infections, and respiratory infection. Staphylococcal infections are becomingly increasingly difficult to treat (Leid et al., 2012). In particular, silver ions have long been known to exert strong inhibitory and bactericidal effects as well as to possess a broad spectrum of antimicrobial activities (Soo-Hwan et al., 2011).

Shahverdi et al. (2007), Shirley et al. (2010), Mohsen et al. (2011), and Soo-Hwan et al. (2011) showed that the AgNPs have potent antibacterial activities against $S$. aureus and E. coli. Nada and Saravanan (2010) showed that silver bionanoparticles from bacteria have inhibitory and bactericidal effect against Methicillin-Resistant Staphylococcus aureus (MRSA). The mechanism of inhibitory action of silver ions on microorganisms is partially known. It is believed that DNA loses its replication ability and cellular proteins become inactivated on $\mathrm{Ag}+$ treatment. In addition, it was also shown that $\mathrm{Ag}+$ binds to functional groups of proteins, resulting in protein denaturation (Nada and Saravanan, 2010).

The silver atoms bind to thiol groups (-SH) in enzymes and subsequently cause the deactivation of enzymes. Silver forms stable S-Ag bonds with thiol-containing compounds in the cell membrane that are involved in trans-membrane energy generation and ion transport (Klueh et al., 2018). It is also believed that silver can take part in catalytic oxidation reactions that result in the formation of disulfide bonds (R-S-S-R).

Silver does this by catalyzing the reaction between oxygen molecules in the cell and hydrogen atoms of thiol groups: water is released as a product and two thiol groups become covalently bonded to one another through a disulfide bond (Davies et al., 2007). Another one of the suggested mechanisms of the antimicrobial activity of silver was proposed that $\mathrm{Ag}+$ enters the cell and intercalates between the purine and pyrimidine base pairs disrupting the hydrogen bonding between the two antiparallel strands and denaturing the DNA molecule (Ranganath et al., 2012).

Literature suggests that there are several mechanisms by which silver nanoparticles could be killing the microorganisms: (i) destructuring the cell wall and ceasing the cell permeability, (ii) formation of free radicals, (iii) inactivating important enzymes by interacting with thiols, (iv) interaction of AgNPs with DNA and interruption of DNA replication and translation and by dephosphorylating the tyrosine residues on peptides inhibiting the signal transduction and growth in bacteria (Kim et al., 2007 and 2011). 
MIC for each extract on each isolate was determined and it was observed that silver nanoparticle had the lowest MIC of $0.22 \mathrm{~g} / \mathrm{ml}$ against $S$. aureus as compared to silver nitrate, chloramphenicol and $C$. papaya leaf extract which had an MIC of $0.32 \mathrm{~g} / \mathrm{ml}$, $0.32 \mathrm{~g} / \mathrm{ml}$ and $0.42 \mathrm{~g} / \mathrm{ml}$ respectively. This could be attributed to the cellular makeup of $S$. aureus it has a thick peptidoglycan layer which makes $C$. papaya leaf extract require a higher concentration to inhibit it growth (Adams and Moss, 2009). While for $S$. typhi, chloramphenicol had the lowest MIC of 0.22 $\mathrm{g} / \mathrm{ml}$ as compared to silver nanoparticle and $C$. papaya leaf extract which had same MIC of 0.32 $\mathrm{g} / \mathrm{ml}$, silver nitrate had the highest MIC of $0.42 \mathrm{~g} / \mathrm{ml}$. Silver nitrate formed a shiny silver coat on the agar which inhibited the growth of the organism on the surface of the agar, this could be linked a unique feature of silver as suggested by Prathna et al. (2014).

For E. coli, chloramphenicol and C. papaya leaf extract had the lowest MIC of $0.32 \mathrm{~g} / \mathrm{ml}$ as compared to silver nitrate and AgNPs which had a higher MIC of $0.42 \mathrm{~g} / \mathrm{ml}$ each. The antimicrobial activity of $C$. papaya leaf extract was different from that of Romasi et al. (2012) possible due fact that he used a male papaya tree for his research or environment factors and the extraction procedure used. The MBC for each extract as presented in Table 5. It was observed that silver nanoparticle, chloramphenicol, C. papaya, and silver nitrate all had bacteristatic effects and not bactericidal effect thus explaining why there was growth at all concentration. Possibly if the extract were left in contact with the organisms for longer period of time, complete bactericidal activity could be achieved, also the concentration were too low to have bactericidal effect on them.

The optical density as presented in Table 6 shows that silver nanoparticle had an absorbance of 0.69 as compared to silver nitrate and C. papaya which had an absorbance of 0.27 and 0.43 respectively. Therefore confirms that nanoparticle has been synthesized because the OD of silver nanoparticle was higher than those of silver nitrate and C. papaya extract.

\section{Conclusion}

Silver has already proved itself as a powerful inorganic compound, and can be used correctly, prevent infection. As a board-spectrum agent, it kills a wide range of microorganisms. Currently, the usage has increased dramatically in the developed world across a huge range of applications, but the impact has not reached the areas of developing world), where the greatest impact could be seen through incorporation into application associated with the production of uncontaminated food and water. The result of this study confirms that the nanoparticles synthesized have satisfactory inhibitions against the test microorganisms.

\section{Conflict of interest statement}

Authors declare that they have no conflict of interest.

\section{References}

Adams, M., Moss, O., 2009. Food Micriobiolgy. $3^{\text {rd }}$ Edn. Tata McGraw-Hill publishers, New Delhi. pp. 132-154.

AOAC, 2015. Official Method or Analysis. 14 ${ }^{\text {th }}$ Edn. Association of Official Analytical Chemical, Washington.

Banala, R.R., Nagati, V.B., Karnat, P.R., 2015. Green sysnthesis and characterization of Carica papaya leaf extract coated silver nanoparticles through X-rays diffraction electron microscopy and evaluation of bactericidal properties. Saudi J. Biol. Sci. 22(5), 637-644.

Baruwati, B., Polshettiwar, V., Varma, R.S., 2009. Glutathione promoted expeditious green synthesis of silver nanoparticles in water using microwaves. J. Green Chem. 11, 926-930.

Cheesbrough, M., 2006. District Laboratory Practice in Tropical Countries. $2^{\text {nd }}$ Edn. Cambridge University Press. pp. 142-430.

Daniel, M.-C., Astruc, D., 2014. Gold nanoparticles: Assembly, supramolecular chemistry, quantum-size-related properties, and applications toward biology, catalysis, and nanotechnology. Chem. Rev. 104(1), 293-346.

Davies D (2007) "Understanding biofilm resistance to antibacterial agents"National Revised Drug Discovery. 2:114-122.

Edwards-Jones, V., 2009. The benefits of silver in hygiene, personal care and healthcare. Int. $\mathrm{H}$. Appl. Microbiol. 49, 147-152.

Fisher, B., Turner, K., Zylstra, M., 2008. Ecosystem services and economic theory: Integration for 
policy relevant research. ecological applications. Int. J. Sci. 18, 2050-2067.

Geetha, N., Geetha, T. S., Manonmani, P., Thiyagarajan, M., 2014. Green synthesis of silver nanoparticles using Cymbopogon citrates (DC) Extract and its antibacterial activity. Austr. J. Basic Appl. Sci. 8(3), 324331.

Kalishwaralal, K., Deepak, V., Pandian, R. K., Kottaisamy Barath-mani, S. M., Kartikeyan, K. S., Gurunathan, B. S., 2010. Biosynthesis of silver and gold nanoparticles using Brevibacterium casei. Colloids Surf. B Biointerfaces. 77(2), 257-262.

Kim, J., Eunye, K., Yu, K., Kim, J., Park, S., Lee, H.J., Kim, S., Park, Y., Park, H., Hwang, C., Kim, Y. K., Lee, Y.S., Jeong, D.H., Cho, M.H., 2007. Antimicrobial effects of silver nanoparticles. J. Nanomed. 3, 95-101.

Klueh, U., Wagner, V., Kelly, S., Johnson, A., Bryers, J.D., 2018. Efficacy of silver-coated fabric to prevent bacterial colonization and subsequent device-based biofilm formation. J. Biomed. Mat. Res. 53, 621-631.

Leid N., Yasab, I., Çelikc, E., Koizhaiganova, M., Saria, O., 2012. Antimicrobial activity of colloidal silver nanoparticles prepared by sol gel method. Digital J. Nanomat. Biostruc. 6, 149-154.

Lin, J., Chen, R., Feng, S., Pan, J., Li, Y., Chen, G., Cheng, M., Huang, Z., Yu, Y., Zeng, H., 2011. A novel blood plasma analysis technique combining membrane electrophoresis with silver nanoparticle-based SERS spectroscopy for potential applications in noninvasive cancer detection. Int. J. Nanomed. 7(5), 655-663.

Mohsen, M., El-Santiel, G., Gaafar, H., El-Gendy, H, El-Beltagi, E., 2011. Nutritional evaluation of berseem. J. Zootech. 2, 66-75.

Morsy, A. A, Ibrahim, A. S., Amin, E.F., Kamel, M.Y., Rifaai, R. A., Hassan, M. K., 2014. Sildenafil ameliorates gentamicin-induced nephrotoxicity in rats: Role of iNOS and Enos. J. Toxicol. 2014, Article ID 489382, 7 pages.

Murthy, M.K., Soumya, K., Srinivas, C., Niranjana, S. R., 2019. Evaluation of Carica papaya leaf extracts for their efficacy on control of bacterial wilt of tomato caused by Ralstonia solanacearum. Int. J. Curr. Microbiol. Appl. Sci. 8(3), 366-380.

Nakkala, J.R., Mata, R., Gupta, A.K., Sadras, S.R., 2014. Green synthesis and characterization of silver nanoparticles using Boerhaavia diffusa plant extract and their antibacterial activity. Indus. Crop Prod. 52, 562-566.

Nanda, A., Saravanan, M., 2010. Extracellular synthesis of silver bionanoparticles from Aspergillus clavatus and its antimicrobial activity against MRSA and MRSE. J. Biotechnol. 77, 214-218.

Nguegno, Y., Tiambeng Jumbo, G. R., Keute Kamdoum, E., Nchongboh, C. G., 2017. Antifungal activities of plant extracts against coffee berry disease caused by Colletotrichum kahawae L. Int. J. Curr. Res. Biosci. Plant Biol. 4(7), 60-66.

Okwu, D. E., Okwu, M.E., 2004. Chemical composition of Spondia mombin plants. J. Agric. Environ. 6, 140-147.

Prathna, T. C., Chandrasekaran, N., Raichur, A.M., Mukherje, A., 2014. Kinetic evolution studies of silver nanoparticles in a bio-based green synthesis process. Colloids Surface Analysis. Physicochemical Engineering Aspects. pp. 212216.

Rangantha, C., Lima, R., Sá Del Fiol, F., Victor, M., 2012. Prospects for the use of new technologies to combat multidrug-resistant bacteria. Front. Pharmacol. 10, 46-57.

Romasi, E., Karina, J., Nexson, A., 2012. Antibacterial activity of papaya leaf extract against pathogenic bacteria. Makara J. Technol. 15(2), 173-177.

Schmid, A., 1992. Nucleosome distruption. J. Cell Biol. 71, 53-64.

Shahverdi, A., Fakhimi, A., Shahverdi, R., Minaian S., 2007. Synthesis and effect of silver nanoparticles on the antibacterial activity of different antibiotics against Staphylococcus aureus and Escherichia coli. Nanomed. 3(2), 168-171.

Shirley, S., Bera, T., Roy, A., Singh, G., Ramachandra Rao, P., Dash, D., 2010. Characterization of enhanced antibacterial effects of novel silver nanoparticles. J. Nanotechnol. 18, 103-112.

Sintubin, L., De Gusseme, B., Van der Meeren, P., Pycke, B. F., Verstraete, W., Boon, N., 2011. The antibacterial activity of biogenic silver and its mode of action. J. Microbiol. 91(1), 153-162.

Sofowara, A., 1993. Medicinal plants and traditional medicine in Africa, Ibadan, Nigeria: Spectrum Books, ${ }^{\text {nd }}$ Edn. pp. 150-158.

Soo-Hwan, K., Lee, H.S., Ryu, D.S., Choi, S. J., Lee, 
D. S., 2011. Antibacterial activity of silvernanoparticles against Staphylococcus aureus and Escherichia coli. Korean J. Microbiol. Biotechnol. 9, 77-85.

Veeraputhiran, V., 2013. Bio-catalytic synthesis of silver nanoparticles. Int. J. Chem. Technol. 5(5), 255-2562.

Winjnhoven, S., Peijnenburg, W., Herberts, C.,
Hagens, I., Oomen, A., Heugens, W., 2015. Nano-silver - a review of available data and knowledge gaps in human and environment risk assessment. Nanotoxicol. 3(2), 109-138.

Xue, M., Brimacombe, M., Chaaban, J., Zimmeerman-Bier, B., Wagner, G., 2008. Concurrent clinical disorders. J. Public Med. 18-20.

\section{How to cite this article:}

Temikotan, T., Daniels, A. O., Samuel, B. J., Akinkugbe, A. O., 2019. The comparative antibacterial effect of aqueous extract of Carica papaya leaves and Carica papaya nanoparticles against selected bacteria.

Int. J. Curr. Res. Biosci. Plant Biol. 6(10), 22-32. doi: https://doi.org/10.20546/ijcrbp.2019.610.003 